\title{
PEMBERDAYAAN EKONOMI KELOMPOK NELAYAN TANGKAP DALAM UPAYA OPTIMALISASI TANGKAPAN IKAN PRODUK PEKASAM KEMASAN DI DESA PANGKALAN SERAI
}

\author{
Evi Marlina ${ }^{1}{ }^{*}$, Hasmalina Nasution ${ }^{2)}$, Isranbidin ${ }^{3)}$ \\ ${ }^{1}$ Prodi Akuntansi, Fakultas Ekonomi dan Bisnis UMRI \\ email: evimarlina@umri.ac.id \\ ${ }^{2}$ Prodi Kimia, Fakultas MIPA dan Kesehatan UMRI \\ email: hasmalina@umri.ac.id \\ ${ }^{3}$ Prodi Akuntansi, Fakultas Ekonomi dan Bisnis UMRI \\ email: isranbidin@umri.ac.id
}

\begin{abstract}
Pangkalan Serai village, one of the villages in the Kampar Kiri Hulu sub-district, is a kampar river basin that is still isolated and a part of its residents are fishermen. Catches fishermen have generally been sold fresh, overlaid (diang on bamboo beds) for fish supplies, or making it into pakasam. Pakasam is a kind of side dish that is processed by fermentation method from fish with special spices which are inserted into small jars or closed jars for about 10 days and after that period it can be cooked like fried or fried. Servicer conducts community partnership programs in this village with guidance of two groups of fishermen, namely the group of fishermen caught in the hamlet of Muara Biwan and the hamlet of Telaga Beras. With this service activity, it is expected that this fishermen group can overcome problems in household products such as fishermen not paying attention to hygienic aspects and product quality standards that are suitable for consumption. So that in the end the pekasam they produce has high economic value and is traded to increase income and family welfare.
\end{abstract}

Keywords: Economic Empowerment, Pekasam Packaging, Capture Fishermen Group

\begin{abstract}
Abstrak
Desa Pangkalan Serai salah satu desa yang berada di kecamatan Kampar Kiri Hulu merupakan daerah aliran sungai kampar yang masih terisolir dan sebahagian warganya berprofesi sebagai nelayan. Hasil Tangkapan nelayan selama ini umumnya dijual segar, disalai (di diang di atas ayaman bambu) untuk persedian ikan, atau membuatnya menjadi pakasam. Pakasam adalah sejenis lauk yang diolah dengan metode fermentasi dari ikan dengan bumbu khusus yang dimasukan ke dalam perigi kecil atau toples tertutup selama lebih kurang 10 hari dan setelah masa tersebut ia dapat dimasak seperti digoreng atau direndang.Pengabdi melakukan program kemitraan masyarakat pada desa ini dengan pembinaan terhadap dua kelompok nelayan yaitu kelompok nelayan tangkap dusun Muara Biwan dan dusun Telaga Beras. Dengan kegiatan pengabdian ini diharapkan pada Kelompok nelayan ini dapat mengatasi permasalahan dalam produk pekasam seperti nelayan tidak memperhatikan aspek higienis dan standar mutu produk yang layak untuk dikonsumsi. Sehingga pada akhirnya pekasam yang mereka hasilkan memiliki nilai ekonomi yang tinggi dan diperjualbelikan untuk meningkatkan penghasilan dan kesejahteraan keluarga.
\end{abstract}

Kata kunci: Pemberdayaan Ekonomi, Pekasam Kemasan, Kelompok Nelayan Tangkap

\section{PENDAHULUAN}

Desa Pangkalan Serai merupakan salah satu desa yang berada di kecamatan Kampar Kiri Hulu. Daerah ini daerah aliran sungai kampar yang masih terisolir. Hal ini disebakan sulitnya transportasi dan ketiadaan listrik sehingga menjadikan harga 
barang cukup tinggi dibanding harga pangan di desa lainnya. Penghasilan masyarakat dibanding desa lainnya masih tergolong rendah dan sumber penghasilan yang menonjol dan potensi eklusif yang dapat diandalkan selama ini untuk mengangkat perekonomian masyarakat setempat belum pula tampak.

Kebanyakan mereka hanya hidup dari penghasilan kebun karet, mencari ikan dan sebagiannya lagi berdagang untuk kebutuhan masyarakat desa. Dengan nawaitu untuk ikut berkontribusi dalam rangka meningkatkan perekonomian masyarakatnya, Pengabdi melihat aspek mata pencaharian mencari ikan dapat diandalkan menjadi sebuah potensi. Dibalik kesusahan ada kemudahan, barangkali itu pepatah yang hampir tepat untuk menterjemahkan situati ini. Bahwa dibalik kesusahan askses, kebodohan dan keterbelakangan, ada aspek yang potensial dapat digali, yaitu potensi ikan sungai asli yang masih banyak.

Selama ini para nelayan atau yang membeli ikan berlebih, jika tidak disalai (di diang di atas ayaman bambu) untuk persedian ikan, mereka membuatnya menjadi pekasam. Pekasam adalah sejenis lauk yang diolah dengan metode fermentasi dari ikan dengan bumbu khusus yang dimasukan ke dalam perigi kecil atau toples tertutup selama lebih kurang 10 hari dan setelah masa tersebut ia dapat dimasak seperti digoreng atau direndang.

Makanan pekasam atau lauk pakasam amat diminati dikalangan masyarakat awam. Selama ini pembuatan, pengolahan dan pengemasan pakasam barulah sebatas cara lain untuk menyimpan lauk-pauk dan agar tidak mubazir karena busuk atau berulat. Walaupun kadang- kadang ada yang memperjual-belikan, tetapi belum terpikir barangkali menjadikannya sebagai usaha produktif yang menjelma sebagai salah satu alternatif sumber ekonomi masyarakatnya dari kalangan kelompok nelayan.

Menurut Taufik, M (2007), pekasam dibuat dengan beberapa tahapan yaitu penyiangan, pencucian ikan, pencampuran sumber karbohidrat (Nasi dan tepung terigu) ke dalam rongga perut ikan, pemasukan ke dalam wadah tertutup dan difermentasi selama 7 hari. Selama proses fermentasi kondisi harus tetap terkontrol dan tidak terdapat udara. Fermentasi pekasam merupakan fermentasi spontan, hanya mengandalkan garam sebagai penyeleksi mikroorganisme. Mikroorganisme yang tumbuh dengan keberadaan garam pada pekasam adalah bakteri asam laktat yang termasuk pada golongan mikroorganisme amilotik. Amilum merupakan karbohidrat utama akan menjadi substrat awal bagi bakteri asam laktat, kemudian dihidrolisis menjadi karbohidrat sederhana. Oleh sebab itu digunakan sumber karbohidrat berupa tepung beras, tepung ketan, tepung maizena, tepung terigu, dan tepung tapioka (Kalista, A., 2012)

Berdasarkan pemikiran diatas pengabdi akan melakukan kegiatan pengabdian pada desa ini dengan pembinaan terhadap dua kelompok nelayan yaitu kelompok nelayan tangkap dusun Muara Biwan dan dusun Telaga Beras . Kelompok nelayan kedua dusun ini adalah nelayan yang sudah turun - temurun.

\section{Permasalahan}

Dari hasil wawancara diperoleh informasi bahwa produk pekasam merupakan alternatif daripada ikan membusuk tidak merupakan suatu usaha produktif. Produk pekasam yang diolah masih secara tradisional permasalahan 
yang pengabdi temui dalam survey awal antara lain:

1. Pengolahan pakasam masih bersifat tradisonal dan dalam jumlah yang sedikit.

2. Produk olahan pakasam belum diuji nilai gizi (protein, lemak dan mineralnya) dan tingkat higenistasnya di laboratorium.

3. Pengolahan pakasam dengan pola tradisonal masih beresiko terhadap kesehatan sakit perut / mules dan meningkatkan asam urat.

4. Pakasam yang telah jadi belum memiliki produk olahan pangan dalam kemasan yang khusus, label khusus dan jaminan waktu lama tahan yang khusus.

5. Pakasam yang telah dihasilkan belum dipasarkan secara modern dan bernilai ekonomi dalam meningkatkan kesejahateraan nelayan

\section{Tujuan Kegiatan dan rencana pemecahan masalah}

Tujuan kegiatan pengabdian ini meliputi tiga area yaitu: (1) Masyarakat menyadari potensi ekonomi dari produk pekasam yang mereka olah. (2) Untuk memperbaiki tehnik pengolahan dan kemasan produk sehingga memenuhi standar mutu dan tahan lebih lama; (3) Untuk mengadakan perbaikan terhadap peralatan dan bahan yang digunakan dalam kegiatan proses produksi dan kemasan produk.

\section{METODE PENGABDIAN}

Kegiatan pengabdian masyarakat tentang pemberdayaan ekonomi kelompok nelayan tangkap dalam upaya optimalisasi tangkapan ikan melalui produk pekasam kemasan di desa Pangkalan Srai Kecamatan Kampar Hulu Kabupaten Kampar. Waktu pelasanaan dari bulan Februari Sampai September 2018. Objek yang menjadi sasaran dari kegiatan pengabdian ini adalah kelopok nelayan tangkap yang terdiri dari dua kelompok yaitu kelompok nelayan tangkap dusun Muara Biwan dan Dusun Telaga Beras.

Metode dalam pelaksanaan

kegiatan ini dilakukan dengan melalui beberapa pendekatan yaitu Metode penyuluhan, Metode Praktis (Tindakan) dan Metode Evaluasi. Metode penyuluhan adalah memberikan informasi pengetahuan kepada kelompok- kelompok nelayan tentang potensi dan peluang produk pekasam kemasan yang memenuhi standar mutu dapat memberikan tambahan penghasilan dan pada akhirnya akan meningkatkan kesejahteraan keluarga mereka. Metode penyuluhan adalah memberikan informasi pengetahuan kepada kelompok- kelompok nelayan tentang potensi dan peluang produk pekasam kemasan yang memenuhi standar mutu dapat memberikan tambahan penghasilan dan pada akhirnya akan meningkatkan kesejahteraan keluarga mereka.

Metode Tindakan, yaitu tindakan yang bertujuan untuk mengembangkan keterampilan baru atau pendekatan baru dan diterapkan langsung serta dikaji hasil evaluasinya. Penerapan metode ini dilakukan oleh mitra dalam mempraktekkan bagaimana cara proses pembuatan produk yang memenuhi strandar mutu produk dan cara kemasan produk pekasam sehingga produk bisa tahan lebih lama. Metode Evaluasi dilakukan untuk memeriksa proses perjalanan program kemitraan masyarakat sekaligus menguraikan fakta-fakta perubahan yang harus dilakukan didalam program tersebut

\section{HASIL DAN PEMBAHASAN}

Kegiatan pengabdian masyarakat ini diawali dengan persiapan pelaksaan kegiatan, yaitu persiapan tim dengan melakukan rapat koordinasi, kesepakatan kerjasama. identifikasi potensi,merancang proses pengolahan dan kemasan pekasam serta penyusunan 
media dan peralatan yang dibutuhkan. Kegiatan selanjutnya adalah persiapan mensosialisasikan bentuk kegiatan kepada pengabdian kepada mitra dalam hal ini Mitra utama program kemitraan masyrakat ini adalah Kelompok Nelayan Tangkap Dusun Muara Biwan dan Kelompok Nelayan Tangkap Dusun Telaga Beras. Kedua mitra ini akan terlibat penuh dalam tahapan kegiatan program kemitraan masyarakat. Bentuk partisipasi mitra adalah:

1. Menyediakan tempat pelaksaaan kegiatan penyuluhan dan pelatihan

2. Mendatangkan dan mengumpulkan kelompok nelayan tangkap pada saat penyuluhan dan pelatihan

3. Bersedia mengikuti semua rangkaian proses pelatihan pengolahan ikan menjadi produk pakasam kemasan yang memenuhi standar mutu proses dan nilai gizi.

4. Bersedia diwawancarai atau mengisi angket dalam rangkan pelaksanaan penyuluhan dan evaluasi keberlanjutan program

Sedangkan

Universitas

Muhammadiyah Riau (UMRI) menyediakan sarana tranportasi darat dan sungai menuju ke lokasi mitra selama program berjalan dan peralatan yang dibutuhkan dalam pelatihan pengolahan ikan menjadi produk pekasam kemasan.

Dalam kegiatan pengabdian tersebut, tim melakukan tiga kali kunjungan. Pada kunjungan pertama tim pengabdi datang untuk melakukan survey awal dan membuat kesepakatan dengan mitra. Disamping itu tim pengabdi melihat proses pembuatan pekasam dari awal pembuatan sampai jadi produk pekasam kemasan. Produk pekasam tradisional tersebut dibawa untuk dijadikan sampel pengujian laboratorium.
Pengujian laboratorium yang dilakukan meliputi analisis komposisi kimia ikan yang terdiri dari atas kadar air, protein, lemak, karbohidrat dan abu. Dari Hasil pengujian laboratorium menunjukkan bahwa pekasam tradisional komposisi kimia menunjukkan kadar air 50,54\%, protein $18,08 \%$, lemak $11,57 \%$, abu $13,67 \%$, garam $12,78 \%$ dan karbohidrat $6,15 \%$

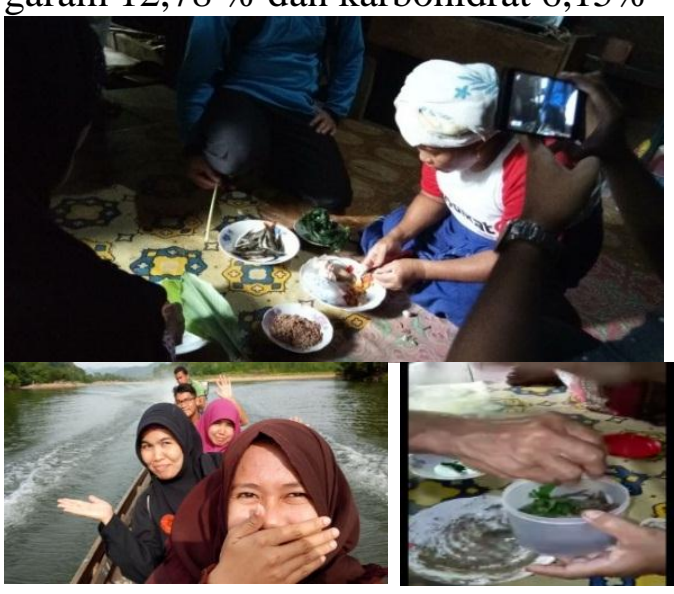

Berdasarkan analisis yang dilakukan oleh tim pengabdian pada kunjungan kedua tim melakukan penyuluhan potensi produk pekasam kemasan. Selanjutnya memberikan pelatihan pengolahan agar lebih higinis dan lebih tahan lama sehingga layak untuk dipasarkan.

Pelatihan pengolahan pekasam kemasan dilakukan dengan mendatangkan orang yang memenag pakar dibidangnya yaitu dengan mendatangkan praktisi dari kecamatan Kuntu Darussalam.

Dalam pelatihan pengolahan peserta sangat antusias dalam memperhatikannya. Dalam sesi ini peserta tidak hanya ditunjukkan mengenai cara pengolahan produk pekasam yang lebih higienis dan tahan lama tetapi juga diperlihatkan bagaimana cara membuat kemasan agar lebih menarik sehingga produk mempunyai nilai ekonomi yang tinggi sehingga layak untuk dipasarkan. 
Pada kunjungan ketiga tim pengabdi melakukan evaluasi dan juga telah berhasil membuatkan label produk pekasam kemasan yang siap untuk dipasarkan.

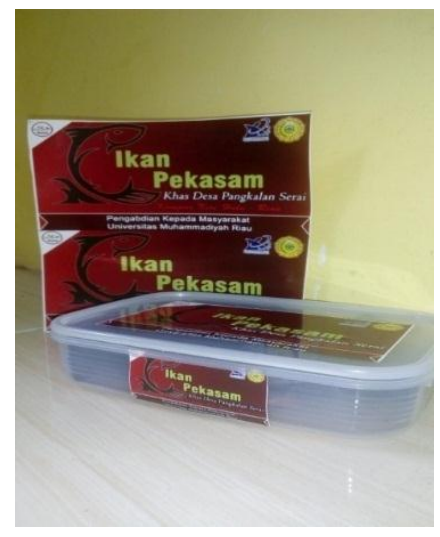

\section{SIMPULAN}

Kesimpulan dari kegiatan pengabdian masyarakat skim iptek bagi masyarakat pada desa Pangkalan Serai

1. Peserta sebagi mitra pelatihan yaitu kelompok nelayan tangkap sangat antusias mengikuti pelatihan dari tim pengabdi dalam hal ini membuat produk pekasam kemasan yang mempunyai nilai ekonomi sehingga diharapkan dapat memberdayakan ekonomi masyarakt khususnya nelayan tangkap

2. Berdasarkan sharing yang dilaksanakan pada saat diskusi, tidak ada kesan buruk dari peserta selama pelaksanaan kegiatan, baik dari segi sarana dan prasarana maupun penyampaian materi, hanya saja perlu dibuat dalam skala yang lebih luas.

3. Pengabdian selanjutnya diarahkan pada sharing masalah pengelolaan potensi daerah karena mereka memiliki sumber daya alam yang melimpah tetapi tidak memiliki nilai ekonomi karena sulitnya transportasi sehingga memakan waktu lama dalam memasarkan produk yang mereka milki.

\section{UCAPAN TERIMAKASIH}

Penulis mengucapkan terima kasih dan apresiasi yang sebesar-besarnya kepada Kemenristekdikti, LPPM UMRI yang telah memberikan bantuan dana dan kepada segenap perangkat desa Pangkalan Serai dan pihak-pihak yang terlibat dalam proses pengabdian ini .

\section{DAFTAR PUSTAKA}

[1] Kalista, A., Supriadi, A., dan Rahmawati, S.H, 2012, Bekasam Lele Dumbo (Clarias gariepinus)

Dengan Penggunaan Sumber Karbohidrat yang Berbeda. Jurnal Fishtech, Volume 1, No 1

[2] Taufik, M., 2007, Karakteristik Kimiawi, mikrobiologis dan organoleptik bekasa dengan variasi konsentrasi penggaraman dan suhu fermentasi, skripsi, Universitas Sriwijaya

[3] Zohra Fatma., 2016, Strategi Pemberdayaan Ekonomi Sosial Masyarakat Nelayan Berbasis Komunitas Ibu Rumah Tangga Di Desa Pusong Baru Kecamatan Banda Sakti Kota Lhokseumawe

[4] Subagio, Windrati, Hermanuadi,. 2011, Pengembangan zero waste processing dari modified cassava flour (MOCAF) guna meningkatkan spinoff klaster kepada masyarakat sekitar 